УДК 159.922.2:612.176

О. Г. СТАВИЦЬКА, І. І. ВОРОБЕЙ

\title{
ПСИХОЛОГІЧНІ ОСОБЛИВОСТІ ВПЛИВУ СТРЕСОСТІЙКОСТІ НА УЧБОВУ ДІЯЛЬНІСТЬ СТУДЕНТІВ
}

Стаття висвітлюе результати теоретичного та емпіричного дослідження стресостійкості, формування та розвиток якої має місце в умовах навчальної діяльності сучасних студентів - психологів. Уточнюеться сутність понять стрес та стресостійкість в ракурсі практичної підготовки студентів психологічних спеціальностей. Виокремлюються особистісні складові та психологічні особливості й чинники розвитку стресостійкості у студентів початківців та студентів випускних курсів.

Ключові слова: стрес, стресостійкість, студентський період, учбова діяльність, психологічні особливості, мотиви навчання.

Статья освещчает результаты теоретического и эмпирического исследования стрессоустойчивости, формирование и развитие которой имеет место в условиях учебной деятельности современных студентов - психологов. Уточняется сущность понятий стресс и стрессоустойчивость в ракурсе практической подготовки студентов психологических специиальностей. Выделяются личностные составляющие и психологические особенности и факторы развития стрессоустойчивости у студентов начальных и студентов выпускных курсов..

Ключевые слова: стресс, стрессоустойчивость, студенческий период, учебная деятельность, психологические особенности, мотивы обучения. 
Постановка проблеми. Проблема стресостійкості зумовлена різким розвитком інформатизації сучасного суспільства. Великий інформаційний потік збільшує навантаження на когнітивну сферу особистості, що призводить до появи функціональних змін в емоційній, поведінковій та особистісній сферах. Часті конфлікти і велике внутрішне напруження можуть викликати складні фізіологічні зміни в організмі людини, а сильна емоційна напруга призводить до появи - стресу. Стресостійкість студентів визначається наявністю стресогенних факторів у навчальному середовищі, наприклад, таких як ситуації іспитів, періоди соціальної адаптації, необхідність особистісного самовизначення у майбутній професійній діяльності. Таким чином, постійний стан стресу і його наслідки становлять серйозну загрозу психічному здоров'ю студентів. Юність - це період формування майбутнього професіонала, рівень стресостійкості якого безпосередньо впливає на успішність його діяльності, стиль життя та суспільну активність. Саме тому дослідження феномену стресостійкості дає можливість зрозуміти як зберегти психічне здоров'я на всіх активних етапах нашого життя, зокрема в студентський період.

Аналіз останніх досліджень та публікацій. Особливу увагу науковці звертають на проблему стійкості особистості до стресу і їі стресогенних чинників (Л. Н. Аболін, Ю.М.Блудов, Л.А.КитаєвСмик, О.А.Кириленко, В.Л.Марищук, Е.А.Мілерян, В.С. Мільман, В.Ф.Моргун, Г.С.Нікіфоров, В.М.Писаренко, С.М.Симоненко, Л.П.Степанова, Р.Бенджамін, Э.Геллгорн, Р.Грін, Р.Лазарус, тощо.). У іншій площині, зокрема питанням інтелектуально-пізнавальних детермінант стресостійкості займались багато радянських та вітчизняних дослідників, а саме: А.Ц.Пунін, Б.А.Вяткін, Ю.Я.Кисельов, Ю.Л.Ханін, А.В. Родіонов, О.А.Чернікова, Г.В.Ложкін, Р.М.Загайнов, тощо, також зарубіжних науковців Е.Сміз, Т.Орлик, Д.Голд, Дж.Тейлор, К.Купер тощо. У їхніх працях підкреслюється значення окремих чинників, які сприяють розвитку стресостійкості особистості, а саме: критичність мислення, передбачення загрозливих подій, перцептивні здібності, мислиннєві образи як випереджаючі елементи самопочуття та поведінки, самоконтроль, а також інші когнітивні чинники, розвиток та регуляція яких підвищує толерантність особистості до умов психологічного стресу.

Метою наукової розвідки $є$ аналіз теоретичних та емпіричних даних щодо вивчення питання психологічних особливостей впливу стресостійкості на учбову діяльність сучасної студентської молоді.

Виклад основного матеріалу. Для психологічного операціоналізування категорія стресу у сучасній науковій літературі використовується у трьох значеннях. По-перше, поняття "стрес" визначається як будь-які зовнішні стимули чи події, що викликають у людини дискомфорт. По-друге, стрес відноситься до суб'єктивної реакції і відображає внутрішній психічний стан напруги і збудження; він інтерпретується як емоції, захисні реакції, що відбуваються у самій людині. По-третє, за У. Кенноном і Г. Сельє, стрес може бути фізичною реакцією організму на запропоновану вимогу чи шкідливий вплив. Функцією таких фізіологічних реакцій, ймовірно, $є$ підтримка поведінкових дій $\mathrm{i}$ психічних процесів для подолання цього стану [2].

Теоретичне опрацювання наукових психологічних та медичних джерел дає можливість стверджувати, що левова частка визначень наголошують на негативному аспекті стресу. Зокрема, Р.С. Немов пояснює поняття “стрес" як “негативний емоційний стан, що виникає в результаті фрустрації або серйозних невдач у житті людини і полягає в неадекватній i дезадаптаційній поведінці" [5].

Навчальна діяльність студентів завжди була пов'язана 3 високим рівнем стресогенного навантаження, а вплив стресорів сучасного середовища додатково збільшує це навантаження. У сучасного студентства досить часто порушується емоційний, когнітивний, поведінковий та мотиваційний компонент діяльності, що пов'язаний зі підвищеним рівнем стресу та зниженням показників стресостійкості.

Стресостійкість являє собою складну системну характеристику людини, яка відображає іiі здатність успішно здійснювати свою діяльність в складних та екстремальних умовах. Згідно Б.Х. Варданяну, стресостійкість можна визначити як «властивість особистості, що забезпечує гармонійне існування всіх компонентів психічної діяльності в емоціогенній ситуації тим самим сприяючи успішному виконанню цієї діяльності »[3].

Стресостійкість - інтегративна властивість особистості, яка характеризується такою взаємодією емоційних, вольвих, інтелектуальний і мотиваційних компонентів психічної діяльності людини, яке забезпечує оптимальне успішне досягнення цілі діяльності в складному емотивному середовищі. Стресостійкість - $є$ інтегральною якістю особистості, основою позитивної соціальної взаємодії людини, яка характеризується емоційною стабільністю, низьким рівнем тривожності, високим рівнем саморегуляції, психологічною готовністю до стресу [4].

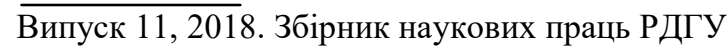


Як вважає А.Л. Церковський, в даний час стресостійкість менш висвітлена у наукових публікаціях, ніж проблема стресу. Однак, на думку А.А. Андрєєвої, дослідження проблеми підвищення стресостійкості не тільки працюючого населення, але i студентів $\epsilon$ не менше актуальним, так як рівень стресостійкості пов'язаний з успішністю навчальної діяльності студентів і їхнім ставленням до власної професії, й як наслідок, впливає на підготовку конкурентоздатних i професійних фахівців[1]. М.Л. Хуторян у своїй праці доводить, що при застосуванні антистресових стратегій перед іспитами, значно зростає стресостійкість студентів під час інтелектуальних випробувань [8]. Молода людина може часто перебувати в стресових та конфліктних ситуаціях, що призводить до збільшення психологічних навантажень, порушення рівноваги нервових процесів, які супроводжуються зниженням стресостійкості. Для виокремлення основних компонентів стресостійкості , вважаємо за необхідне розглянути структуру конфліктостійкості, яка складається 3 наступних компонентів: емоційний - полягає в умінні людини контролювати свій емоційний стан у перед конфліктних та конфліктних ситуаціях, у здатності відкрито виявляти свої емоції без приниження особистості опонента, не переходити в депресивні стани у разі затяжного конфлікту чи програшу в ньому (відображає рівень і характер збудливості психіки та ії вплив на успішність спілкування в складних ситуаціях); вольовий - це здатність до свідомого контролю й володіння собою, терпимості до інших, самовладання й самоконтролю, несприйняття провокаційних дій опонента; пізнавальний - це стійкість функціонування пізнавальних процесів особистості; цей компонент включає вміння визначати початок перед конфліктної ситуації, здійснювати об'єктивний аналіз причин іiі виникнення, прогнозувати розвиток конфлікту й можливі наслідки, швидко приймати правильні рішення; мотиваційний - забезпечує адекватність прагнень у конфлікті, їх спрямованість на пошук шляхів розв'язання суперечностей, здатність коригувати інтереси залежно від зміни обставин і конкретної ситуації; психомоторний - забезпечує правильність дій, їх чіткість і відповідність ситуації. Полягає в умінні володіти своїм тілом, контролювати свої жести, міміку [9].

В якості складових компонентів особистісного когнітивного ресурсу стресостійкості можна виокремити наступні елементи, саме: функціональний компонент - характеризується він наявністю відповідного потенціалу когнітивних функцій (уваги, пам'яті, мислення) молодих людей, які $\epsilon$ необхідними складовими реалізації виходу із конкретної стресової ситуації; компонент самооцінки демонструє рівень основних елементів підготовленості людини до підвищення власної стресостійкості, полягає у з'ясуванні причин суб'єктивно низького або високого оцінювання стресової ситуації, адекватності такої оцінки та моделювання шляхів досягнення вищого рівня стійкості до стресів; стильовий компонент - містить показники, які характеризують індивідуальносвоєрідні прийоми переробки інформації про актуальну та стресову ситуацію; соціально-когнітивний компонент - характеризується наявністю соціально-психологічних особливостей «викривлення» людиною інформаційного потоку, що відбувається за умов наявності ірраціональних та неконструктивних уявлень про свої можливості і часто є причиною виникнення стресових станів; когнітивно-поведінковий компонент - характеризує стратегії дій людини, спрямовані на подолання стресових ситуацій, а також характеризує особистий поведінковий тип у діяльності, що може сприяти виникненню стресових ситуацій [7].

На основі структурних компонентів стресостійкості виділяють наступні іiі властивості: адаптаційно - діяльнісний механізм, регуляція, захист, стійкість. Зокрема С. Анохіна, розглядає стресостійкість як динамічний процес адекватного реагування, що постійно змінюється в залежності від ситуації, та стресора. Стресостійкість молодої людини проявляється в здатності адаптуватися до стресових ситуацій зберігаючи високу ефективність власної життєдіяльності. Адаптація може приймати форму протидії стресору, уникнення чи пристосування до впливу стресу [7]. Стресостійкість - одна $з$ основних значимих характеристик особистості, що дає їй можливість розкривати свій потенціал та індивідуальність, через власну суб'єктність. Молода людина може стати суб'єктом діяльності в тому випадку, якщо діяльність носить цілісний характер. Виділяють наступні функціональні компоненти цілісної діяльності: 1) цілеспрямованість, 2) інформаційний компонент, 3) прогнозування, 4) прийняття рішень, 5) організація та виконання діяльності, 6) спілкування й комунікація, 7) контроль, 8) оцінка, 9) корекція [6]. Таким чином, проблема стресостійкості пов'язана з аспектами місця і ролі суб'єкта в житті суспільства [2]. Що в свою чергу актуалізує механізми психологічної самоорганізації, самоврядування та саморегуляції при розкритті творчого потенціалу особистості, через це першочергового значення набувають завдання підготовки в системі освіти стресостійкого майбутнього спеціаліста.

Аналіз результатів дослідження. Для вивчення психологічних особливостей стресостійкості та їі впливу на учбову діяльність студентів нами було організоване та проведене експериментальне дослідження. У ньому взяли участь 34 студенти психологічного факультету, віком 19 - 21 рік.

Випуск 11, 2018 Збірник наукових праць РДГУ. 
Аналізуючи емпіричні результати дослідження стресостійкості студентів - психологів 4 та 2 курсів ми отримали показники, що свідчать про чіткі межі середнього рівня стресостійкості в обох вибірках досліджуваних (див. рис. 1).

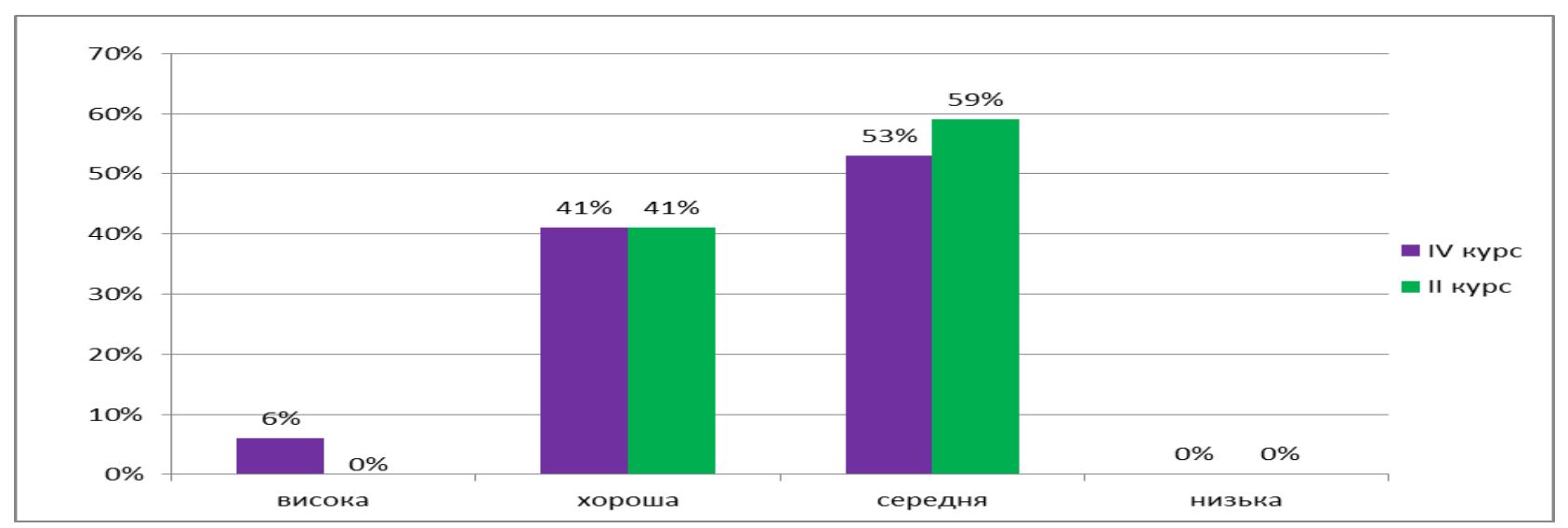

Рис. 1. Кількісні показники підгруп різного рівня стресостійкості студентів - психологів 2-го та 4-го курсів (у\%)

Це вказує на те, що внутрішня напруженість студентської молоді, яка спровокована зовнішньо - суб'єктними стресорами, змушує організм постійно перебувати в стані кооперації для підтримання загального гомеостазу психічних, фізіологічних та внутрішньо - особистісних процесів.

Високі показники стресостійкості (див. рис.1) спостерігаються лише в одній вибірці студентів психологів 4 курсу, тобто здатність не піддаватися впливу стресових чинників, зберігаючи при цьому психічне та фізичне здоров'я, можлива лише при чіткому розумінні власних сил та переваг, досвіду міжособистісної інтеракції та розумінні психологічних особливостей людей. Низький рівень стесостійкості не притаманний жодній групі досліджуваних, що свідчить про психологічну готовність студентів - психологів різних курсів до професійної діяльності в майбутньому.

Для виявлення взаємозв'язків між всіма показниками означених психічних явищ (саморозвитку, рівня стесостійкості та мотивів навчальної діяльності у студентів), діагностованих комплексом методик, нами було використано метод рангової кореляції Спірмена. Проаналізувавши отримані показники кореляційного аналізу стресостійкості, саморозвитку та мотивів навчальної діяльності 2-го та 4-го курсів можемо говорити про виявлені позитивні зв'язки в наступних групах: стресостійкість та саморозвиток: $\left(\mathrm{r}_{\mathrm{s}}=0.164, \mathrm{r}_{\mathrm{s}}=-0.347 ; \mathrm{p} \leq 0.05\right)$; стресостійкість та комунікативні мотиви навчання: $\left(\mathrm{r}_{\mathrm{s}}=0.095, \mathrm{r}_{\mathrm{s}}=-0.212 ; \mathrm{p} \leq 0.05\right)$; стресостійкість та мотиви уникнення: $\left(\mathrm{r}_{\mathrm{s}}=-0.128\right.$, $\left.\mathrm{r}_{\mathrm{s}}=-0.076 ; \mathrm{p} \leq 0.05\right) ;$ стресостійкість та мотиви престижу; $\left(\mathrm{r}_{\mathrm{s}}=0.298 ; \mathrm{r}_{\mathrm{s}}=-0.025 ; \mathrm{p} \leq 0.05\right)$; стресостійкість та професійні мотиви: $\left(\mathrm{r}_{\mathrm{s}}=0.01 ; \mathrm{r}_{\mathrm{s}}=-0.393 ; \mathrm{p} \leq 0.05\right)$; стресостійкість та мотиви творчої самореалізації: $\left(\mathrm{r}_{\mathrm{s}}=-0.248, \mathrm{r}_{\mathrm{s}}=-0.02 ; \mathrm{p} \leq 0.05\right)$; стресостійкість та навчально - пізнавальні мотиви: $\left(\mathrm{r}_{\mathrm{s}}=\right.$ $\left.-0.076, \mathrm{p} \leq 0.05 ; \mathrm{r}_{\mathrm{s}}=-0.499, \mathrm{p} \leq 0.01\right) ;$ стресостійкість та соціальні мотиви: $\left(\mathrm{r}_{\mathrm{s}}=-0.498, \mathrm{p} \leq 0.01 ; \mathrm{r}_{\mathrm{s}}=0.004\right.$, $\mathrm{p} \leq 0.05)$.

Встановлено, що обернений слабкий кореляційний зв'язок з фактором стресостійкості мають такі мотиви - навчання, комунікативні мотиви, мотиви престижу та мотиви творчої самореалізації, а це в свою чергу свідчить, що на перший план в студентів - психологів виступає відчуття гармонії психічного та фізичного здоров'я, здатність активно керувати власним життям, при цьому без реалізації егоцентричних та особистісно - професійних мотивів. Схожий зв'язок прослідковується в обох групах досліджуваних між показниками стресостійкості та мотивами уникнення, тобто при хороших ресурсних механізмах подолання стресогенних ситуацій, мотивація до уникнення конфронтації з соціальним середовищем буде менш вираженою, можливо через відсутність страху до невдачі.

Зафіксовано кореляційний зв'язок між мотивами навчально - пізнавальної діяльності та стресостійкісті у четвертокурсників. У процесі навчання, коли отримання нових знань та вмінь переплітається 3 особистісними прагненнями, виникає можливість їх практичної реалізації в буденному житті, що сприяе підвищенню показників стресостійкості через новизну апробації отриманого теоретичного знання, особливо у майбутніх психологів, які незабаром стануть молодими спеціалістами.

Отриманий значний кореляційний зв'язок $\left(\mathrm{r}_{\mathrm{s}}=-0.498 ; \mathrm{p} \leq 0.01\right)$ показників стресостійкості та соціальних мотивів навчання в другокурсників. У стабільних, гармонійних, сприятливих 
умовах життя майбутні спеціалісти психологи націлені надавати допомогу людям щодо вирішення їхніх психологічних проблем, при вирішенні психологічних проблем пересічної людини. Та, в силу соціально - економічних та політичних негараздів у суспільстві, підвищення рівня стресу та стресогенних факторів знижують можливості та прагнення допомогати іншим, через недостатні внутрішні ресурси та досвід. Зафіксовано, що стресостійкість має помірний обернений кореляційний зв'язок $\left(\mathrm{r}_{\mathrm{s}}=-0.347 ; \mathrm{p} \leq 0.05\right)$ з показниками саморозвитку в четвертокурсників тобто для актуалізації та розвитку власного потенціалу необхідні хороші адаптаційні здібності для подолання зовнішнішньо - суб'єктних стресорів сучасного ритму життя. Отже, отримані результати показують, що між показниками саморозвитку, рівнем стесостійкості та мотивами навчальної діяльності у студентів - психологів існують статистично значимі зв'язки.

Висновки та перспективи подальших розвідок. У процесі подолання стресу кожна людина використовує власні внутрішні потенції, які формуються на основі наявного у неї особистісного досвіду і психологічних резервів. Тому, стресостійкість виступає інтегративною властивістю особистості, яка характеризується взаємодією емоційних, вольвих, інтелектуальний і мотиваційних компонентів психічної діяльності людини, які забезпечують оптимальне успішне досягнення цілі діяльності в складному емотивному середовищі. У процесі навчання коли отримання нових знань та вмінь переплітається з особистісними прагненнями підвищується можливість їх практичної реалізації в буденному житті й відповідно підвищення показників стресостійкості майбутніх психологів, які незабаром стануть молодими спеціалістами через новизну апробації отриманого теоретичного знання. Для актуалізації та розвитку власного потенціалу необхідні хороші адаптаційні здібності, що сприятимуть подоланню зовнішнішньо - суб'єктних стресорів сучасного ритму життя.

Стресостійкість виступає конгломератом інтеро - та екстероцептивних факторів, що впливають на життєдіяльність особистості в соціальній та професійно - учбовій діяльності. Тому розуміння та розвиток стресостійкості у студентства $\epsilon$ необхідною умовою їхньої особистісної та професійної реалізації в сучасному глобалізованому світі. Перспективним напрямком дослідження $€$ подальше вивчення психологічних особливостей формування стресостійкості як фактора успішної учбової діяльності студентів, з метою розробки ефективних засобів розвитку та формування даного явища.

\section{Список використаних джерел}

1. Андреева А. А. Стрессоустойчивость как фактор развития позитивного отношения к учебной деятельности у студентов : автореф. дис. ... канд. психол. наук : 19.00.07 / А. А. Андреева. Тамбов, 2009. - 27 с.

2. Бодров В. А. Информационный стресс : учеб. пособ. для вузов / В. А. Бодров. - М. : ПЕР СЭ, 2000. - $352 \mathrm{c}$.

3. Комарова И. А. Коррекция уровня психоэмоционального стресса у студентов во время учебного процесса : автореф. дис. ... канд. медиц. наук : 03.00.13 / И. А. Комарова. - Курган, 2009. $23 \mathrm{c}$.

4. Куприянов Р. В Психодиагностика стресса : практикум / М-во образования и науки РФ, Казан. гос. технол. ун-т / Р. В. Куприянов, Ю. М. Кузьмина. - Казань : КНИТУ, 2012. - 212 с.

5. Немов Р. С. Психология : словарь-справочник . В 2 ч. Ч. 2. / Р. С. Немов. - М. : ВЛАДОСПРЕСС, 2003. - $352 \mathrm{c}$. $326 \mathrm{c}$.

6. Психофизиология : учеб. для вузов / под ред. Ю. И. Александрова. - СПб. : Питер, 2006. -

7. Степанов С. С. Популярная психологическая энциклопедия / С. С. Степанов. - М. : Эксмо, 2005. $-672 \mathrm{c}$.

8. Хуторная М. Л. Развитие стрессоустойчивости студентов в условиях интеллектуальных испытаний : автореф. дис. ... канд. психол. наук : 19.00.13 / М. Л. Хуторная. - Тамбов, 2007. - 25 с.

9. Циганчук Т. В. Динаміка переживання стресу студентами 1-4 курсів ВН3 / Т. В. Циганчук // Проблеми загальної та педагогічної психології : зб. наук. пр. Ін-ту психології ім. Г. С. Костюка НАПН України / за ред. С. Д. Максименка. - Київ, 2010. - Вип. ХІІ, ч. 6. - С. 360-367.

\section{References}

1. Andreyeva A. A. Resistance to stress as factor of development of the positive relation to educational activity in students : avtoref. yew. ... edging. психол. sciences : 19.00.07 / А. А. Andreyeva. Tambov, 2009. $-27 \mathrm{c}$. 
2. Bodrov V. A. Information stress : studies. пособ. for higher education institutions / V. A. Bodrov. - M. : PER SE, 2000. - 352 p.

3. Komarova I. A. Correction of level of a psychoemotional stress at students during educational process : avtoref. yew. ... edging. психол. sciences : 03.00.13 / I. А. Komarova. - Kurgan, 2009. - 23 c.

4. Kupriyanov R. V. Psikhodiagnostika of a stress : a practical work / M-at image. and sciences of the Russian Federation, Kazan. state. tekhnol. un-t / R. V. Kupriyanov, Yu. M. Kuzmina - Kazan : KNITU, 2012. $-212 \mathrm{p}$.

5. Nemov R. S. Psychology: dictionary reference : In 2 H. P. 2. / R. S. Nemov. - M. : VLADOSPRESS publishing house, 2003. $-352 \mathrm{w}$.

6. Psychophysiology : the textbook for higher education institutions / under the editorship of Yu. I. Alexandrov. - SPb. : St. Petersburg, 2006. -326 p.

7. Stepanov S. S. Popular psychological encyclopedia / S. S. Stepanov. - M. : Eksmo publishing house, 2005. $-672 \mathrm{p}$.

8. Hutornaya M. L. Development of resistance to stress of students in the conditions of intellectual tests : avtoref. yew. ... edging. психол. sciences : 19.00.13 / M. L. Hutornaya. - Tambov, 2007. - 25 p.

9. Cy`ganchuk T. V. Dy`namika perezhy`vannya stresu studentamy` 1-4 kursiv VNZ / T. V. Cy`ganchuk // Problemy zah. ta ped. psykholohii : zb. nauk. pr. In-tu psykholohii im. H. S. Kostiuka NAPN Ukrainy / za red. S. D. Maksymenka. - Kyyiv, 2010. - Vyp. XII, p. 6. - S. 360-367.

\section{O. G. Stavytska, I. I. Vorobey PSYCHOLOGICAL PECULIARITIES OF THE STRESS INFLUENCE ON THE STUDENTS' EDUCATIONAL ACTIVITIES}

Article highlights the results of theoretical and empirical research of stress resistance, formation and development of which takes place in the conditions of educational activity of modern students psychologists. Personal components and psychological characteristics and factors of stress resistance of beginner students and graduate students have been determined. Huge information flow increases the load on the cognitive sphere of the individual, which leads to functional changes in the emotional, behavioral and personal spheres. Frequent conflicts and great internal stress can cause complex physiological changes in the human body, and strong emotional stress leads to stress. Students' stress resistance is determined by presence of stress factors in the learning environment, such as exam situations, periods of social adaptation, need for personal self-determination in future professional activities. To study psychological characteristics of stress resistance and its impact on the educational activities of students, we organized and conducted the experimental study. While learning process, when acquisition of new knowledge and skills intertwined with personal aspirations, the possibility of their practical implementation in everyday life increases and, accordingly, increasing the indicators of stress resistance of future psychologists, who will soon become young professionals through the novelty of testing the theoretical knowledge. Stress resistance acts as a conglomerate of interoceptive and exteroceptive factors affecting the life of the individual in social and vocational training activities. Therefore, understanding and development of stress resistance of students is a necessary condition for their personal and professional implementation in the modern globalized world.

Key words: stress, stress resistance, student period, educational activity, psychological peculiarities, motives of studying. 